Article

\title{
Selective Hydrogenolysis of Glycerol and Crude Glycerol (a By-Product or Waste Stream from the Biodiesel Industry) to 1,2-Propanediol over $\mathrm{B}_{2} \mathrm{O}_{3}$ Promoted $\mathrm{Cu} / \mathrm{Al}_{2} \mathrm{O}_{3}$ Catalysts
}

\author{
Malaya R. Nanda ${ }^{1}$, Zhongshun Yuan ${ }^{1}$, Hengfu Shui ${ }^{2}$ and Chunbao (Charles) Xu ${ }^{1,2, *}$ \\ 1 Department of Chemical and Biochemical Engineering, Western University, London, ON N6GA5B9, Canada; \\ nandamalaya9@gmail.com (M.R.N.); zyuan25@uwo.ca (Z.Y.) \\ 2 School of Chemistry \& Chemical Engineering, Anhui University of Technology, Ma'anshan 243002, China; \\ shuihf@sina.com \\ * Correspondence: cxu6@uwo.ca; Tel.: +1-519-661-2111 (ext. 86414)
}

Academic Editor: Keith Hohn

Received: 29 April 2017; Accepted: 23 June 2017; Published: 25 June 2017

\begin{abstract}
The performance of boron oxide $\left(\mathrm{B}_{2} \mathrm{O}_{3}\right)$-promoted $\mathrm{Cu} / \mathrm{Al}_{2} \mathrm{O}_{3}$ catalyst in the selective hydrogenolysis of glycerol and crude glycerol (a by-product or waste stream from the biodiesel industry) to produce 1,2-propanediol (1,2-PDO) was investigated. The catalysts were characterized using $\mathrm{N}_{2}$-adsorption-desorption isotherm, Inductively coupled plasma atomic emission spectroscopy (ICP-AES), X-ray diffraction (XRD), ammonia temperature programmed desorption $\left(\mathrm{NH}_{3}-\mathrm{TPD}\right)$, thermogravimetric analysis (TGA), temperature programmed reduction (TPR), and transmission electron microscopy (TEM). Incorporation of $\mathrm{B}_{2} \mathrm{O}_{3}$ to $\mathrm{Cu} / \mathrm{Al}_{2} \mathrm{O}_{3}$ was found to enhance the catalytic activity. At the optimum condition $\left(250{ }^{\circ} \mathrm{C}, 6 \mathrm{MPa} \mathrm{H}_{2}\right.$ pressure, $0.1 \mathrm{~h}^{-1} \mathrm{WHSV}$ (weight hourly space velocity), and $5 \mathrm{Cu}-\mathrm{B} / \mathrm{Al}_{2} \mathrm{O}_{3}$ catalyst), $10 \mathrm{wt} \%$ aqueous solution of glycerol was converted into 1,2-PDO at $98 \pm 2 \%$ glycerol conversion and $98 \pm 2 \%$ selectivity. The effects of temperature, pressure, boron addition amount, and liquid hourly space velocity were studied. Different grades of glycerol (pharmaceutical, technical, or crude glycerol) were used in the process to investigate the stability and resistance to deactivation of the selected $5 \mathrm{Cu}-\mathrm{B} / \mathrm{Al}_{2} \mathrm{O}_{3}$ catalyst.
\end{abstract}

Keywords: boron oxide; $\mathrm{Cu} / \mathrm{Al}_{2} \mathrm{O}_{3}$; glycerol; crude glycerol; 1,2-propanediol

\section{Introduction}

Owing to its environmental and sustainability benefits, biodiesel, produced mainly by transesterification of vegetable oils or animal fats, has been regarded as a promising substitute to the fossil-based transportation fuels. The biodiesel industry has, however, generated very large amounts of crude glycerol as its primary by-product or waste stream that needs to be disposed. The current global market of glycerol is likely to be saturated because of its limited utilization in different fields [1]. Therefore, there is an urgent need of finding new applications for glycerol or crude glycerol for the sustainability of the biodiesel industry. Chemical valorization is one of the pathways in which glycerol could be converted to high-value chemicals for various applications, which could burst the demand for glycerol.

In fact, catalytic conversion of glycerol to different value-added chemicals, such as acrolein [2], solketal [3,4], glyceric acids [5,6], and propanediols [7-10], are of great industrial importance. Recently, much attention has been given to valorize glycerol to 1,2-propanediol (1,2-PDO) via catalytic hydrogenolysis [11-16]. 1,2-PDO, a three-carbon diol with a stereogenic centre at the central carbon, is one of the high-value chemicals with wide applications. It is mainly used for manufacturing polyester 
resins, liquid detergents, cosmetics, tobacco humectants, flavors and fragrances, personal care products, paints, animal feed, anti-freezing agents, and pharmaceuticals [17,18]. Conventionally, it is produced by hydration of propylene oxide derived from petroleum-based propylene either by chlorohydrin or by hydroperoxide processes [19]. Therefore, the development of an alternative renewable process for the production of 1,2-PDO is highly desired from an environmental point of view.

Hydrogenolysis of glycerol to 1,2-PDO over metal-based catalysts, such as $\mathrm{Pt}, \mathrm{Ru}, \mathrm{Ir}, \mathrm{Rh}, \mathrm{Pd}$, $\mathrm{Ni}$, and $\mathrm{Cu}$, has been extensively reported in the literature [20-28]. While noble-metal and Ni-based catalysts have demonstrated excellent catalytic activity, these catalysts often promote excessive $\mathrm{C}-\mathrm{C}$ cleavage, resulting in the formation of degraded, lower-carbon compounds, such as ethylene glycol, ethanol, methanol, and methane [29]. Cu-based catalysts demonstrated to be superior catalysts with excellent catalytic activity [27,28]. Sato, et al. [27], found that copper nanoparticle catalyst prepared from $\mathrm{Cu}-\mathrm{Al}$ hydrotalcite gave an excellent yield of 1,2-propanediol in the hydrogenolysis of glycerol, achieving $100 \%$ conversion of glycerol with $93 \%$ 1,2-PDO selectivity at ambient hydrogen pressure through dehydration-hydrogenation via hydroxyacetone (HA). Hydrogenolysis of glycerol to different chemical compounds is given in Scheme 1. The conversion of glycerol to 1,2-PDO involves the selective cleavage of a $\mathrm{C}-\mathrm{O}$ bond at one of the primary carbon atoms without breaking the $\mathrm{C}-\mathrm{C}$ bonds of glycerol to eliminate a water molecule, forming acetol as an intermediate compound or side-product, and subsequently absorb a molecule of hydrogen through hydrogenation, thus, requiring a catalyst with dehydration sites which are usually acid sites and hydrogenation sites which usually need a transition metal. $\mathrm{Cu}$ is known to be active for $\mathrm{C}-\mathrm{O}$ bond hydro-dehydration and less active for $\mathrm{C}-\mathrm{C}$ bond cleavage [30]. The catalytic activity of $\mathrm{Cu}$-based catalyst on different supports such as $\mathrm{SiO}_{2}$ [31], $\mathrm{ZnO}$ [32,33], $\mathrm{Al}_{2} \mathrm{O}_{3}$ [34,35], $\mathrm{Cr}_{2} \mathrm{O}_{3}$ [14], zeolite [36], $\mathrm{MgO}$ [2], etc., have been investigated. Most of these studies were carried out in a batch reactor, while a continuous-flow process would be more desirable due to the ease of the process scale-up and the potential for commercialization of the process.

Promoters are usually incorporated in a catalyst to enhance its activity and stability. A suitable promoter increases the catalyst surface area and dispersion of the catalyst particles by preventing the agglomeration and sintering of the metals and improves the mechanical strength of the catalyst. $\mathrm{Rh}, \mathrm{Pd}$, and silicotungstic acid $\left(\mathrm{H}_{4} \mathrm{SiW}_{12} \mathrm{O}_{40}\right)$ can be effective promoters for $\mathrm{Cu}$-based catalysts for hydrogenolysis of glycerol to 1,2-PDO, however, the use of these expensive promoters in this process would limit its commercialization potential $[17,34,37]$. The use of inexpensive promoters, such as boric acid, has been reported in $\mathrm{Ni} / \mathrm{SiO}_{2}[38]$ and $\mathrm{Cu} / \mathrm{SiO}_{2}$ [27] catalyst systems with excellent interaction with the metal atoms, resulting a high metal dispersion with a suitable acidity and an outstanding catalytic activity. Hence, it would be interesting to investigate the catalytic behavior of boric acid-doped $\mathrm{Cu} / \mathrm{Al}_{2} \mathrm{O}_{3}$ catalyst for the hydrogenolysis of glycerol.

The selective hydrogenolysis of glycerol to 1,2-PDO has been investigated either in the presence or absence of any solvent $[39,40]$. For instance, Gandaris et al. demonstrated a novel catalytic conversion process by employing formic acid as both a solvent and a source of hydrogen [21,41]. Chaminand et al. examined the influence of solvent (aqueous and organic) on the hydrogenolysis of glycerol over a $\mathrm{Rh} / \mathrm{C}$ catalyst in a batch reactor at $180{ }^{\circ} \mathrm{C}, 80 \mathrm{bar} \mathrm{H}_{2}$, and for $168 \mathrm{~h}$, and reported a higher glycerol conversion (32\%) in the organic solvent (sulfolane) than in water (21\%) [24]. As an inexpensive green solvent, water is certainly more desirable than any organic solvents; however, it is challenging to carry out the selective glycerol hydrogenolysis reaction in aqueous medium since water is formed as a by-product during the reaction, which could create a thermodynamic barrier to shift the reaction in the forward direction. Considering the environmental impact of organic solvents and the green/low-cost nature of water, water has been commonly used as a solvent for the selective hydrogenolysis of glycerol to $1,2-\mathrm{PDO}[29,42,43]$.

The use of crude glycerol as a feedstock for the synthesis of propylene glycol is a valuable attempt for the economical production of propylene glycol and the sustainability of the biodiesel industry. However, as mentioned earlier, crude glycerol contains various impurities derived from the biodiesel production processes, including water, sodium or potassium hydroxides, esters, fatty acids, and 
alcohols. When crude glycerol is used as a feedstock for the conversion reaction, the impurities would cause operating problems by either deactivating the catalyst or plugging the reactors [11]. There is not much research carried so far on the hydrogenolysis of crude glycerol in a flow reactor. The present work is aimed to investigate on conversion of both pure glycerol and crude glycerol into 1,2-PDO in aqueous medium over inexpensive $\mathrm{Cu} / \mathrm{Al}_{2} \mathrm{O}_{3}$ catalysts promoted by boric acid in a continuous-flow reactor. Therefore, the results of this work will contribute to new knowledge in the literature and open a new window to utilize the crude glycerol for high-value products.

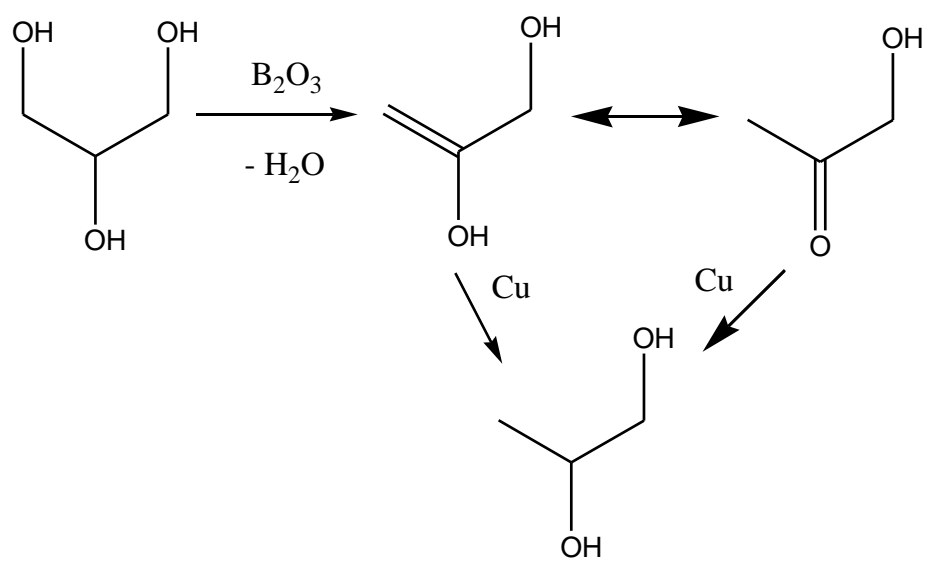

Scheme 1. Hydrogenolysis of glycerol to 1,2-PDO.

The scope of the present work is to study the performance of Cu-based catalysts loaded on highly-dispersed $\mathrm{B}_{2} \mathrm{O}_{3}$ (which would partially transfer to boric acid in the presence of water) on alumina supports for the glycerol hydrogenolysis reaction. The effects of various process parameters ( $\mathrm{Cu}$ loading, B addition amount, temperature, $\mathrm{H}_{2}$ pressure, weight hourly space velocity, purity of the glycerol feedstock, etc.) on the reaction were also investigated. Moreover, the stability of the selected $\mathrm{B}_{2} \mathrm{O}_{3}$-loaded Cu-based catalyst was tested.

\section{Results and Discussion}

\subsection{Catalyst Characterization}

The textural properties of $\mathrm{Cu} / \mathrm{Al}_{2} \mathrm{O}_{3}$ with $\mathrm{B}_{2} \mathrm{O}_{3}$ promoter measured by Brunauer-Emmett-Teller (BET) theory with $\mathrm{N}_{2}$ adsorption-desorption isotherms are presented in Table 1. In the Table, an initial improvement in the pore volume and the surface area of the catalyst can be observed by the incorporation of $0.25 \% \mathrm{~B}$ to $\mathrm{Cu} / \mathrm{Al}_{2} \mathrm{O}_{3}$ sample indicating that $\mathrm{B}_{2} \mathrm{O}_{3}$ helps preventing the agglomeration $\mathrm{Cu}$ catalyst. However, the excess of $\mathrm{B}_{2} \mathrm{O}_{3}$ loading reduced the surface area and pore volume, which could be due to the coverage of the sample surface and blocking of some pores by $\mathrm{B}_{2} \mathrm{O}_{3}$.

Table 1. Textural properties of the fresh/spent $\mathrm{Cu} / \mathrm{Al}_{2} \mathrm{O}_{3}$ catalysts loaded with various amounts of $\mathrm{B}_{2} \mathrm{O}_{3}$ determined by $\mathrm{N}_{2}$ adsorption-desorption.

\begin{tabular}{|c|c|c|c|c|c|c|}
\hline Catalyst & $\begin{array}{l}\text { BET Surface } \\
\text { Area }\left(\mathrm{m}^{2} / \mathrm{g}\right)\end{array}$ & $\begin{array}{c}\text { Total Pore } \\
\text { Volume (cc/g) }\end{array}$ & $\begin{array}{c}\text { Pore } \\
\text { Diameter (̊̊) }\end{array}$ & $\begin{array}{l}\text { Amount of } \\
\mathrm{Cu}\left(w \mathrm{t}^{\mathrm{T}} \%\right)^{1}\end{array}$ & $\begin{array}{l}\text { Amount of } \\
B(w t \%)^{1}\end{array}$ & $\begin{array}{l}\text { Amount of } \\
\text { Al }(w t \%)\end{array}$ \\
\hline $\mathrm{Al}_{2} \mathrm{O}_{3}$ & 231 & 0.54 & 103 & & & \\
\hline $5 \mathrm{Cu} / \mathrm{Al}_{2} \mathrm{O}_{3}$ & 152 & 0.47 & 100 & & & \\
\hline $5 \mathrm{Cu}-0.25 \mathrm{~B} / \mathrm{Al}_{2} \mathrm{O}_{3}$ & 167 & 0.49 & 96 & & & \\
\hline $5 \mathrm{Cu}-1 \mathrm{~B} / \mathrm{Al}_{2} \mathrm{O}_{3}$ & 131 & 0.47 & 99 & 4.8 & 0.9 & 92 \\
\hline $5 \mathrm{Cu}-3 \mathrm{~B} / \mathrm{Al}_{2} \mathrm{O}_{3}$ & 109 & 0.32 & 87 & & & \\
\hline $5 \mathrm{Cu}-1 \mathrm{~B} / \mathrm{Al}_{2} \mathrm{O}_{3}$ (Spent) & 91 & 0.25 & 83 & 4.5 & 0.2 & 30 \\
\hline
\end{tabular}

\footnotetext{
${ }^{1}$ Measured by ICP-AES.
} 
The XRD patterns of the reduced catalyst samples of $\mathrm{Cu} / \mathrm{Al}_{2} \mathrm{O}_{3}$ (containing $5 \mathrm{wt} \% \mathrm{Cu}$ and $0-3 \mathrm{wt} \% \mathrm{~B}$ ) are displayed in Figure 1. In this figure, all the catalysts have similar XRD patterns and the XRD peaks at $2 \theta=36.3,45.5,60.6$, and 66.5 are ascribed to the $X$-ray diffraction of $\gamma-\mathrm{Al}_{2} \mathrm{O}_{3}$ in these catalysts. From Figure 1, one can observe that there is a small peak at $44{ }^{\circ} \mathrm{C}$ in $5 \mathrm{Cu} / \mathrm{Al}_{2} \mathrm{O}_{3}$, typical of copper metal, disappeared after incorporation of $\mathrm{B}_{2} \mathrm{O}_{3}$. No X-ray diffraction lines of either $\mathrm{Cu}$ or $\mathrm{B}$ species were detected (although all catalysts contain $5 \mathrm{wt} \% \mathrm{Cu}$, above the detection limit of $\mathrm{XRD}$ ) in $5 \mathrm{Cu} \times B / \mathrm{Al}_{2} \mathrm{O}_{3}$ catalysts, suggesting a high dispersion of the corresponding $\mathrm{Cu}$ particles in these catalysts.

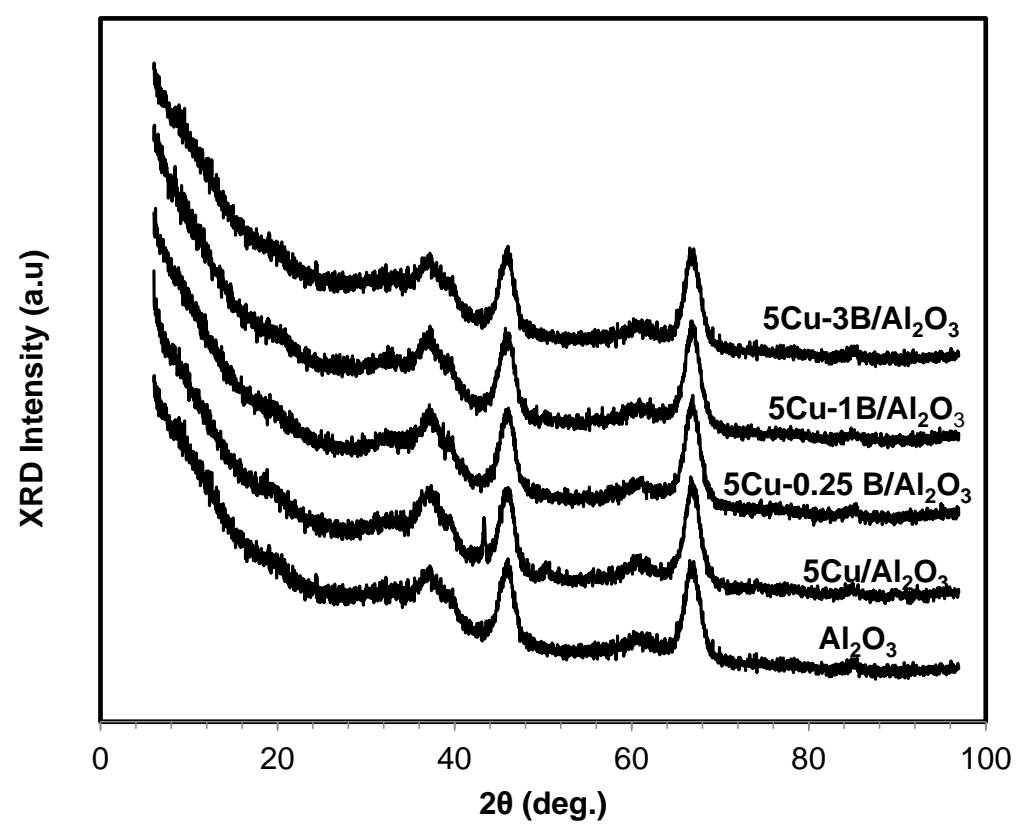

Figure 1. XRD pattern of the fresh $\mathrm{Cu} / \mathrm{Al}_{2} \mathrm{O}_{3}$ catalysts loaded with various amounts of $\mathrm{B}_{2} \mathrm{O}_{3}$.

The reducibility of the catalysts was investigated using temperature-programmed reduction (TPR). Figure 2 illustrates the hydrogen TPR profiles of all the catalyst samples used in this study. Except $5 \mathrm{Cu}-0.25 \mathrm{~B} / \mathrm{Al}_{2} \mathrm{O}_{3}$, all other samples have a well-resolved single peak in the temperature range of $160-280{ }^{\circ} \mathrm{C}$. The symmetric $\mathrm{H}_{2}-\mathrm{TPR}$ profile of the reduction peak indicates the homogeneous nature of the reduced samples and the formation of small, monodispersed metallic $\mathrm{Cu}$ particles [34], although in $5 \mathrm{Cu}-0.25 \mathrm{~B} / \mathrm{Al}_{2} \mathrm{O}_{3}$ there exists a main reduction peak and a weak-shoulder peak in the temperature range of $180-220^{\circ} \mathrm{C}$, indicating the presence of two different $\mathrm{Cu}$ valence states $\left(\mathrm{Cu}^{+1}\right.$ and $\left.\mathrm{Cu}^{0}\right)$ [44]. In the $\mathrm{H}_{2}$-TPR profiles (Figure 2), a shift in the reduction peak towards higher temperature with the increase in $\mathrm{B}$ content was observed. Similar observations have been reported in the literature where the authors ascribed the peak-shift to the strong interaction between $\mathrm{CuO}$ and $\mathrm{B}_{2} \mathrm{O}_{3}$ [27].

The catalyst acidity has an important role in the bifunctional mechanism (dehydration and hydrogenation) of selective hydrogenolysis of glycerol to 1,2-PDO [20]. Therefore, $\mathrm{NH}_{3}$-TPD was used to investigate the strength of surface acid sites. The $\mathrm{NH}_{3}$-TPD profiles of the catalysts are presented in Figure 3. Ammonia is a basic molecule and is adsorbed by the acid sites of the catalyst. The higher is the ammonia desorption temperature, the stronger is acidity of the sites. The larger desorption area, the greater the acid sites. In the figure, a peak between 150 and $250{ }^{\circ} \mathrm{C}$ was observed for all the catalysts indicating that weak-intermediate acid sites were present on the catalyst surface [42]. As clearly shown by the $\mathrm{NH}_{3}$-TPD profiles of the catalysts (presented in Figure 3), the intensity and area of desorption peaks gradually increased, reached maximum for $5 \mathrm{Cu}-3 \mathrm{~B} / \mathrm{Al}_{2} \mathrm{O}_{3}$ with the increase of boron content, proving the increase in acidity of the catalyst surface [38]. Based on the peak areas, the number of acid sites in $5 \mathrm{Cu}-3 \mathrm{~B} / \mathrm{Al}_{2} \mathrm{O}_{3}$ is almost double that of the $5 \mathrm{Cu} / \mathrm{Al}_{2} \mathrm{O}_{3}$ catalyst. 
Based on the above characterization results, the roles of addition of $\mathrm{B}_{2} \mathrm{O}_{3}$ may be summarized here: the addition of $\mathrm{B}_{2} \mathrm{O}_{3}$ leads to higher reducibility of copper oxides and increased dispersion of $\mathrm{Cu}$ particles in the $5 \mathrm{Cu}-\mathrm{xB} / \mathrm{Al}_{2} \mathrm{O}_{3}$ catalysts, which would account for the increased 1,2-PDO selectivity of the catalysts. On the other hand, the addition of $\mathrm{B}_{2} \mathrm{O}_{3}$ results in increased acidity of the $5 \mathrm{Cu}-\mathrm{xB} / \mathrm{Al}_{2} \mathrm{O}_{3}$ catalysts, which explains the enhanced glycerol conversion, as discussed previously.

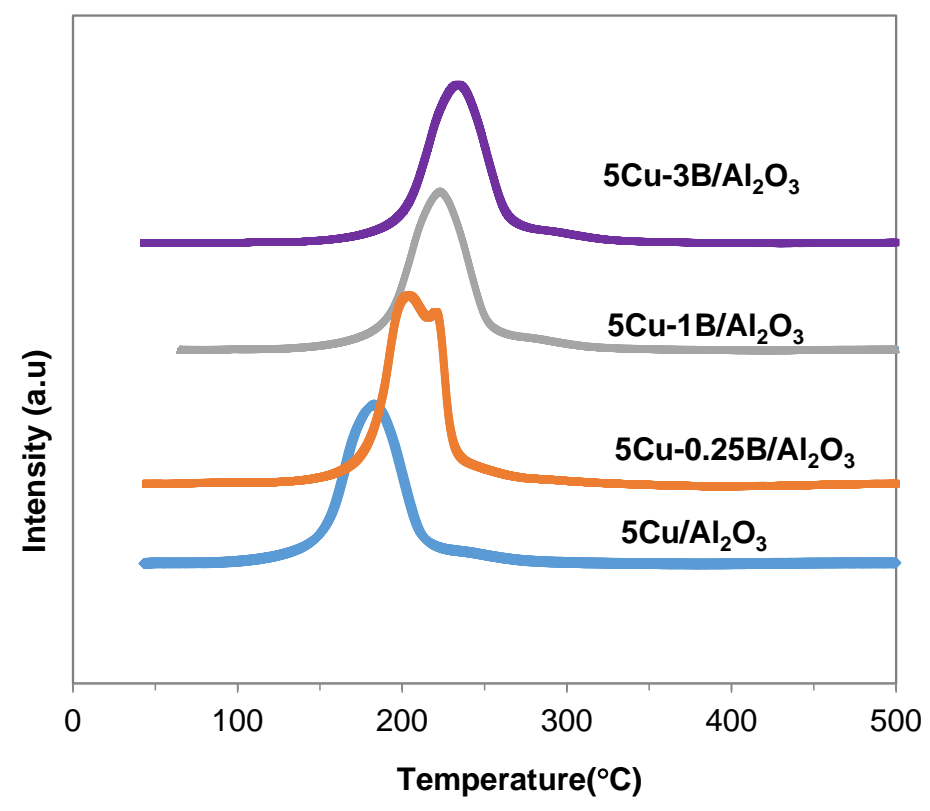

Figure 2. $\mathrm{H}_{2}$-TPR profiles of the fresh $\mathrm{Cu} / \mathrm{Al}_{2} \mathrm{O}_{3}$ catalysts loaded with various amounts of $\mathrm{B}_{2} \mathrm{O}_{3}$.

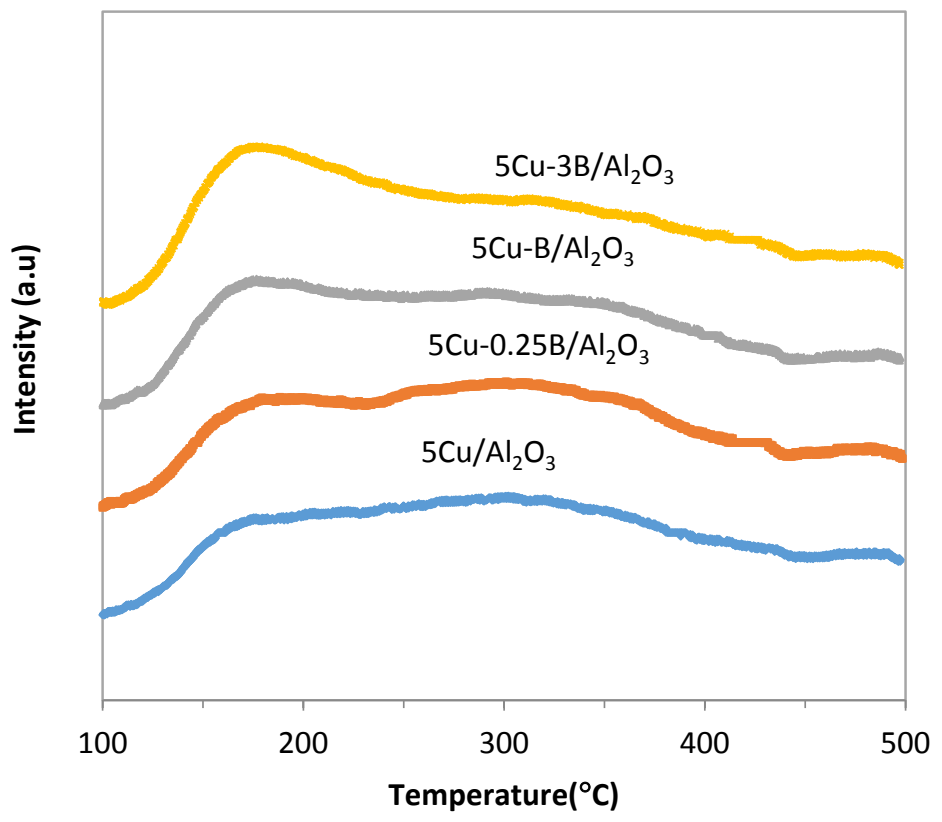

Figure 3. $\mathrm{NH}_{3}$-TPD profiles of the catalysts.

\subsection{Influence of Process Parameters}

\subsubsection{Influence of $\mathrm{Cu}$ Loading}

The effects of $\mathrm{Cu}$ loading on the activity of $\mathrm{Cu} / \mathrm{Al}_{2} \mathrm{O}_{3}$ catalysts for glycerol hydrogenolysis were investigated at $230{ }^{\circ} \mathrm{C}, 5 \mathrm{MPa} \mathrm{H}_{2}$ and $2 \mathrm{~h}^{-1} \mathrm{WHSV}$ and the results are summarized in Table 2. It can 
be seen that with the increase of $\mathrm{Cu}$ loading, the glycerol conversion first increased and reached a maximum of $71 \%$ at a $\mathrm{Cu}$ loading of $5 \mathrm{wt} \%$. This is attributed to the presence of extra active sites produced by the incorporation of $\mathrm{Cu}$ which accelerated the reaction process. When further increasing the $\mathrm{Cu}$ loading from $5 \mathrm{wt} \%$ to $15 \mathrm{wt} \%$, the glycerol conversion and 1,2-PDO selectivity remained almost unchanged, likely due to the reduced dispersion of $\mathrm{Cu}$ particles and the blocked pores of the catalyst caused by agglomeration of excess $\mathrm{Cu}$ particles in the catalysts with too high $\mathrm{Cu}$ loadings. However, the selectivity of 1,2-PDO remains almost unaffected by catalyst loading and was found to be in the range of $85-87 \%$ in all the cases. Since $5 \mathrm{wt} \%$ loading of $\mathrm{Cu}$ metal over alumina demonstrated a promising catalytic performance, it was selected for all the further experiments. From the Table, the main by-products from $\mathrm{Cu} / \mathrm{Al}_{2} \mathrm{O}_{3}$ catalyzed glycerol hydrogenolysis are acetol, ethylene glycol (EG), plus relatively much smaller amounts of compounds denoted as "others" in Table 2.

Table 2. Influence of $\mathrm{Cu}$ loading on activity of $\mathrm{Cu} / \mathrm{Al}_{2} \mathrm{O}_{3}$ catalysts for glycerol hydrogenolysis (reaction conditions: $230{ }^{\circ} \mathrm{C}, 5 \mathrm{MPa} \mathrm{H}_{2}$ and $2 \mathrm{~h}^{-1}$ WHSV).

\begin{tabular}{cccccc}
\hline \multirow{2}{*}{ Catalyst } & Conversion (\%) & \multicolumn{4}{c}{ Selectivity (\%) } \\
\cline { 2 - 5 } & & $\mathbf{1 , 2 - P D O}$ & EG & Acetol & Others ${ }^{\mathbf{1}}$ \\
\hline $\mathrm{Al}_{2} \mathrm{O}_{3}$ & $5 \pm 1.2$ & $38 \pm 0.3$ & - & $57 \pm 32$ & $5 \pm 0.4$ \\
$1 \mathrm{Cu} / \mathrm{Al}_{2} \mathrm{O}_{3}$ & $26 \pm 2.3$ & $85 \pm 3.0$ & $2 \pm 0.2$ & $11 \pm 0.1$ & $2 \pm 0.2$ \\
$3 \mathrm{Cu} / \mathrm{Al}_{2} \mathrm{O}_{3}$ & $45 \pm 2.0$ & $88 \pm 2.0$ & $1 \pm 0.1$ & $7 \pm 0.6$ & $4 \pm 0.6$ \\
$5 \mathrm{Cu} / \mathrm{Al}_{2} \mathrm{O}_{3}$ & $71 \pm 3.0$ & $87 \pm 1.0$ & $3 \pm 0.2$ & $6 \pm 0.2$ & $2 \pm 0.1$ \\
$10 \mathrm{Cu} / \mathrm{Al}_{2} \mathrm{O}_{3}$ & $70 \pm 2.0$ & $87 \pm 2.0$ & $1 \pm 0.1$ & $4 \pm 0.5$ & $3 \pm 0.3$ \\
$15 \mathrm{Cu} / \mathrm{Al}_{2} \mathrm{O}_{3}$ & $68 \pm 1.0$ & $86 \pm 3.0$ & $2 \pm 0.2$ & $6 \pm 0.4$ & $3 \pm 0.4$ \\
\hline
\end{tabular}

${ }^{1}$ Others include 1-propanol, 2-propanol, ethanol and methanol.

\subsubsection{Influence of $B$ Incorporation}

The catalytic effect of $\mathrm{B}$ was studied on $5 \mathrm{Cu} / \mathrm{Al}_{2} \mathrm{O}_{3}$ at the reaction conditions of $230{ }^{\circ} \mathrm{C}, 6 \mathrm{MPa} \mathrm{H}_{2}$, $2 \mathrm{~h}^{-1}$ (WHSV), and at a hydrogen flow of $100 \mathrm{~mL} / \mathrm{min}$, and the results are summarized in Figure 4 . The glycerol conversion and 1,2-PDO selectivity for the catalyst $5 \mathrm{Cu} / \mathrm{Al}_{2} \mathrm{O}_{3}$ without $\mathrm{B}$ was $73 \%$ and $87 \%$, respectively. As $\mathrm{B}$ was introduced into the $5 \mathrm{Cu} / \mathrm{Al}_{2} \mathrm{O}_{3}$ catalyst, both catalytic activity and 1,2-PDO selectivity were improved significantly. At these experimental conditions, $5 \mathrm{Cu}-1 \mathrm{~B} / \mathrm{Al}_{2} \mathrm{O}_{3}$ demonstrated the superior performance among other $\mathrm{B}_{2} \mathrm{O}_{3}$ incorporated catalysts and achieved $80 \%$ glycerol conversion with $98 \%$ selectivity towards 1,2-PDO. Similar results have been reported by $\mathrm{Zhu}$ et al. for $\mathrm{B}_{2} \mathrm{O}_{3}$-doped $\mathrm{Cu} / \mathrm{SiO}_{2}$ catalysts for the synthesis of propylene glycol [27]. The authors attributed the enhancement in the glycerol conversion to the synergistic effect caused by $\mathrm{Cu}-\mathrm{B}$ surface interaction which accelerated the surface activity of $\mathrm{Cu}$ metal. The improvement in the selectivity towards 1,2-PDO was directly associated with the enhanced hydrogenation activity of $\mathrm{Cu}$ towards acetol. A further increase in boron content reduced the glycerol conversion and 1, 2-PDO selectivity, which might be due to the masking effect of boron over the $\mathrm{Cu}$ catalyst surface and the pores, as evidenced by the substantial decreases in both BET surface area and total pore volume (Table 1).

There are two possible explanations for the enhancement effects of $\mathrm{B}_{2} \mathrm{O}_{3}$. First, $\mathrm{B}_{2} \mathrm{O}_{3}$ can act as a Lewis acid, promoting the dehydration of glycerol to acetol. Secondly, in the calcinations stage, $\mathrm{Cu}\left(\mathrm{NO}_{3}\right)_{2}$ would first decompose to form $\mathrm{CuO}$, then $\mathrm{CuO}$ reacts with $\mathrm{B}_{2} \mathrm{O}_{3}$ to from copper borate, which will convert to well-dispersed nano $\mathrm{Cu}$ particles after $\mathrm{H}_{2}$ reduction. $\mathrm{B}_{2} \mathrm{O}_{3}$ is usually added to impart thermal stability of a catalyst [45]. Tan et al. used $\mathrm{CoB} / \mathrm{Al}_{2} \mathrm{O}_{3}$ in Fischer-Tropsch synthesis (under conditions comparatively harsher than ours) and reported enhanced thermal stability of the catalyst owing to the presence of boron oxide at the surface sites of the catalyst [45]. However, the mechanism of thermal stabilization of boron incorporated catalysts is not clear. One possible explanation is owing to the strong interaction between $\mathrm{Ni}$ and $\mathrm{B}$, and $\mathrm{Co}$ and $\mathrm{B}$ in $\mathrm{Ni}-\mathrm{B} / \mathrm{SiO}_{2}$ and $\mathrm{Co}-\mathrm{B} / \mathrm{MCM}-41$, respectively, leading to suppression of metal sintering and improvement in the dispersion of active species $[38,45]$. Yin et al. reported that the incorporation of $\mathrm{B}_{2} \mathrm{O}_{3}$ to $\mathrm{Cu}$-based 
catalysts generated more active sites of $\mathrm{Cu}$ in dimethyl oxalate hydrogenation [46]. He et al. [30] proposed that the acidity and electron affinity of $\mathrm{B}_{2} \mathrm{O}_{3}$ are higher than that of $\mathrm{SiO}_{2}$ support, which is favorable for the formation of strong interactions between $\mathrm{Cu}$ and boron species in $\mathrm{Cu}-\mathrm{B} / \mathrm{SiO}_{2}$ catalysts $[47,48]$. Thus, in the present study, the stabilizing effect of $\mathrm{B}_{2} \mathrm{O}_{3}$ could also be due to the strong interaction between $\mathrm{Cu}$ and $\mathrm{B}$ species which helped retard the aggregation of $\mathrm{Cu}$ particles during calcination, reduction, and reaction, as evidenced by $\mathrm{H}_{2}$-TPR profiles (Figure 2) clearly indicating a shift in the reduction peak towards higher temperature with an increase in B content.

In addition, as evidenced by the $\mathrm{NH}_{3}$-TPD profiles of the non-reduced catalysts (presented in the Figure 3), the addition of $\mathrm{B}_{2} \mathrm{O}_{3}$ enhanced the acidity of the $\mathrm{Cu} / \mathrm{Al}_{2} \mathrm{O}_{3}$ catalysts, as similarly reported in the literature [38]. The improved acidity would also play a role in the enhancement of catalytic activities of the catalysts.

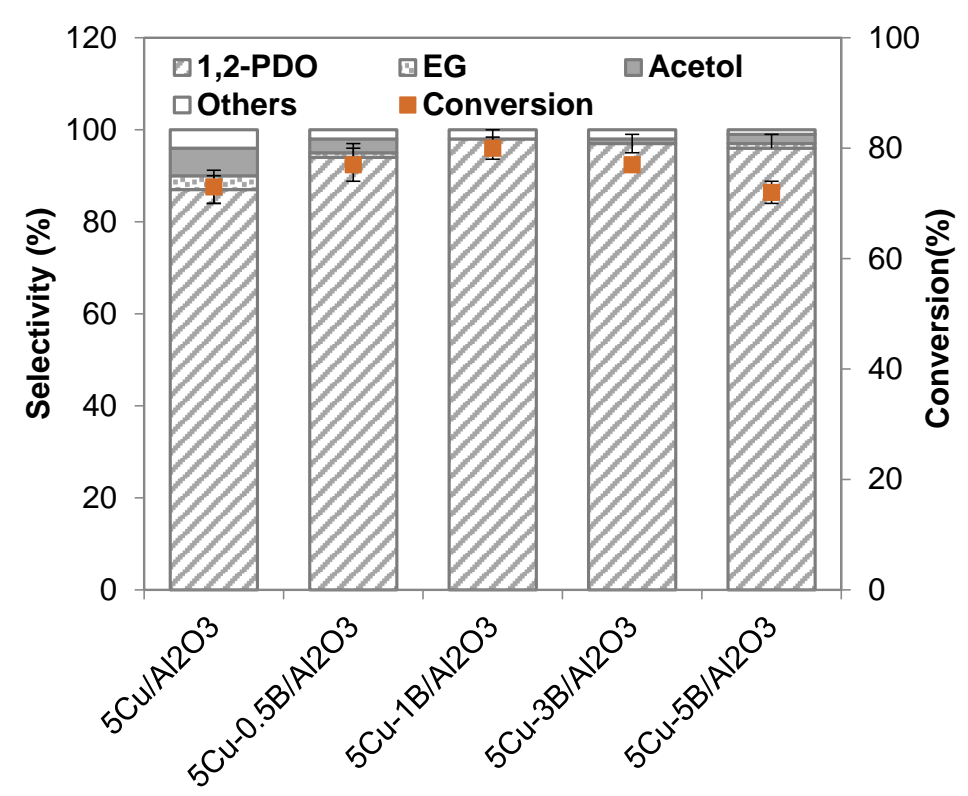

Figure 4. Influence of $\mathrm{B}$ loading $(0-5 \mathrm{wt} \%)$ on $5 \mathrm{Cu} / \mathrm{Al}_{2} \mathrm{O}_{3}$ on activity of $\mathrm{Cu} / \mathrm{Al}_{2} \mathrm{O}_{3}$ catalysts for glycerol hydrogenolysis (experimental conditions: $230{ }^{\circ} \mathrm{C}, 6 \mathrm{MPa} \mathrm{H}_{2}, 10 \mathrm{wt} \%$ aq. glycerol, WHSV $0.2 \mathrm{~h}^{-1}$ ).

\subsubsection{Influence of Temperature}

The reaction temperature dependence of glycerol hydrogenolysis over $5 \mathrm{Cu}-\mathrm{B} / \mathrm{Al}_{2} \mathrm{O}_{3}$ is illustrated in Figure 5. As expected, the glycerol conversion improved dramatically from $15 \%\left(170{ }^{\circ} \mathrm{C}\right)$ to $99 \%$ $\left(270{ }^{\circ} \mathrm{C}\right)$ as the temperature elevated. While, an initial insignificant decrease in the 1,2-PDO selectivity from $98 \%\left(180^{\circ} \mathrm{C}\right)$ to $96 \%\left(250^{\circ} \mathrm{C}\right)$ followed by a remarkable decrease to $85 \%$ at $270{ }^{\circ} \mathrm{C}$ was observed. It is assumed that the low selectivity at high temperatures is related to the formation of large amounts of undesired by-products, such as the over-hydrogenolysis products 1-propanol, 2-propanol, and the degradation products methanol, ethanol, and ethylene glycol. The selectivity to 1,2-PDO remains high in the moderate range of temperature $\left(200-250^{\circ} \mathrm{C}\right)$, indicating that it is favorable to promote the hydrogenolysis of glycerol to 1,2-PDO in this range of temperatures, as described previously [43].

The reaction mechanisms of glycerol hydrogenolysis to 1,2-propanediol has been reported in the literature $[49,50]$. Based on the products formed in the present study it is believed that the reaction involves a dehydration and hydrogenation mechanism in which dehydration of glycerol forms acetol which undergoes hydrogenation in the next step to form 1,2-propanediol. The dehydration mainly controlled by the acidity of the catalyst and the hydrogenation occurs on the active metal sites [18]. The other steps involved in the process include the excess hydrogenolysis of 1,2-PDO to form 1-propanol/2-propanol, cleavage of the $\mathrm{C}-\mathrm{C}$ bond in glycerol to give ethylene glycol and methanol. 


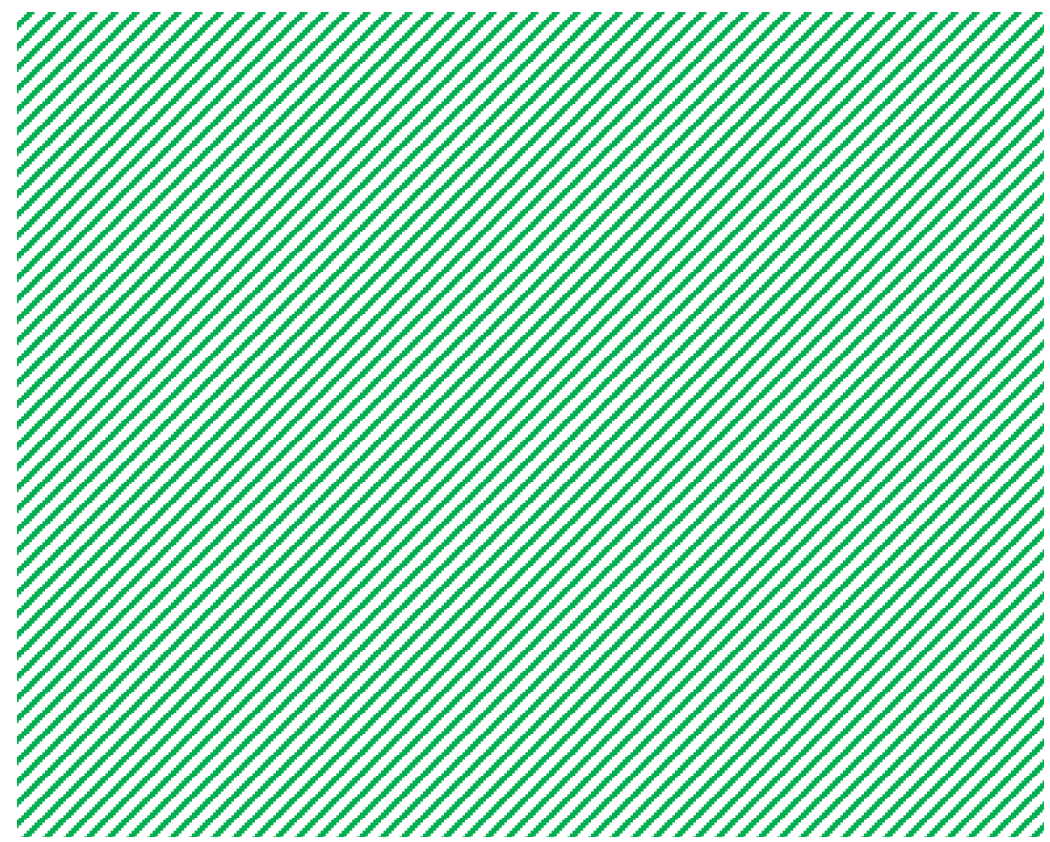

Figure 5. Influence of temperature on the activity of $5 \mathrm{Cu}-1 \mathrm{~B} / \mathrm{Al}_{2} \mathrm{O}_{3}$ catalyst for glycerol hydrogenolysis (5 $\mathrm{MPa} \mathrm{H}, 10 \mathrm{wt} \%$ aq. glycerol and WHSV $0.2 \mathrm{~h}^{-1}$ ).

\subsubsection{Influence of Hydrogen Pressure}

Figure 6 shows effects of hydrogen pressure (2-8 MPa) on the performance of $5 \mathrm{Cu}-1 \mathrm{~B} / \mathrm{Al}_{2} \mathrm{O}_{3}$ catalyst for glycerol hydrogenolysis $\left(240{ }^{\circ} \mathrm{C}, 10 \mathrm{wt} \%\right.$ aq. glycerol and WHSV $\left.0.4 \mathrm{~h}^{-1}\right)$. Generally, both the glycerol conversion and 1,2-PDO selectivity increased by increasing the hydrogen pressure from $2 \mathrm{MPa}$ to $6 \mathrm{MPa}$, as expected. A further increase in hydrogen pressure did not result in any significant increase in the glycerol conversion and 1,2-PDO selectivity. At $6 \mathrm{MPa} \mathrm{H}_{2}$, the glycerol conversion and 1,2-PDO selectivity attained $45 \%$ and $95 \%$, respectively. The low hydrogen pressure ( $2 \mathrm{MPa}$ ) caused incomplete hydrogenation of acetol to 1,2-PDO.

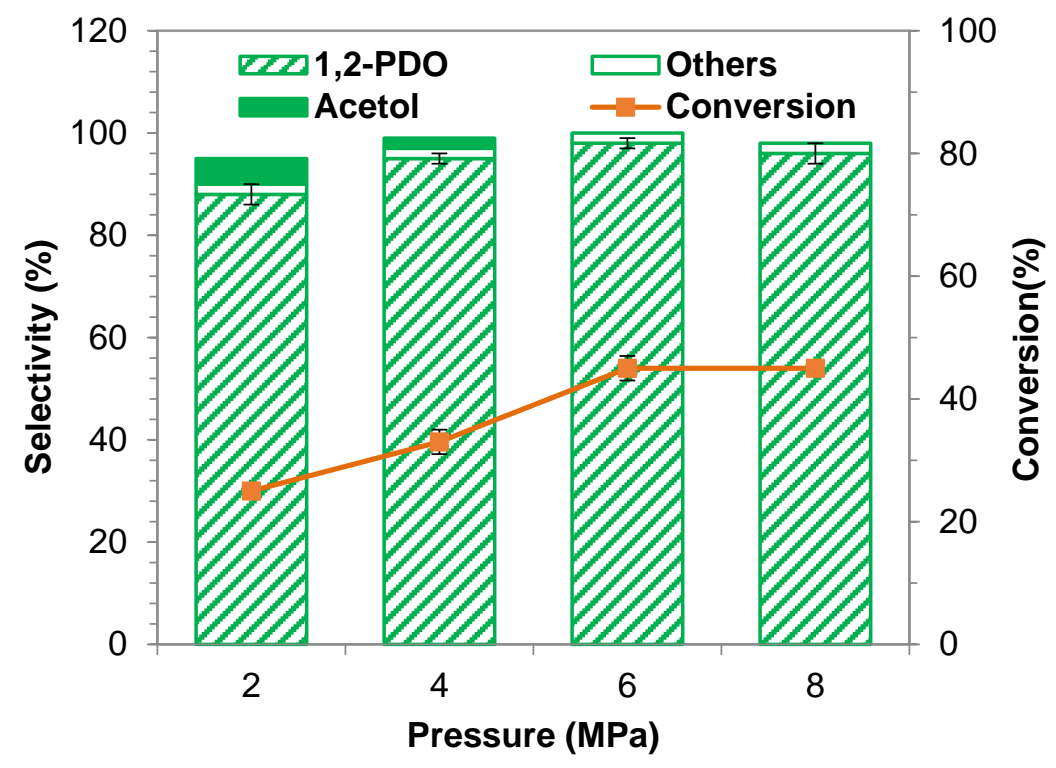

Figure 6. Effects of hydrogen pressure (2-8 MPa) on the performance of $5 \mathrm{Cu}-1 \mathrm{~B} / \mathrm{Al}_{2} \mathrm{O}_{3}$ catalyst for glycerol hydrogenolysis $\left(240^{\circ} \mathrm{C}, 10 \mathrm{wt} \%\right.$ aq. glycerol and WHSV $\left.0.4 \mathrm{~h}^{-1}\right)$. 


\subsubsection{Influence of Weight Hourly Space Velocity (WHSV)}

Effects of WHSV $\left(0.05-0.8 \mathrm{~h}^{-1}\right)$ on the performance of $5 \mathrm{Cu}-1 \mathrm{~B} / \mathrm{Al}_{2} \mathrm{O}_{3}$ catalyst for glycerol hydrogenolysis $\left(250{ }^{\circ} \mathrm{C}, 6 \mathrm{MPa} \mathrm{H}_{2}, 10 \mathrm{wt} \%\right.$ aq. glycerol) were studied by changing the flow rate of the feedstock and the results are shown in Figure 7. It is evident that the glycerol conversion drops with increasing WHSV because of the shortened residence time. However, the selectivity of 1,2-PDO remains almost unchanged (96-98\%) when the WHSV varies between 0.1 and $0.8 \mathrm{~h}^{-1}$, but it was as low as $78 \%$ when the WHSV was reduced to $0.05 \mathrm{~h}^{-1}$, which is likely caused by the excessive hydrogenolysis reaction converting 1,2-PDO to ethylene glycol and other lower alcohols like ethanol and methanol at too long a residence time. Hence, to get a good conversion of glycerol with high selectivity to 1,2-PDO, the optimal WHSV is likely $0.1 \mathrm{~h}^{-1}$.

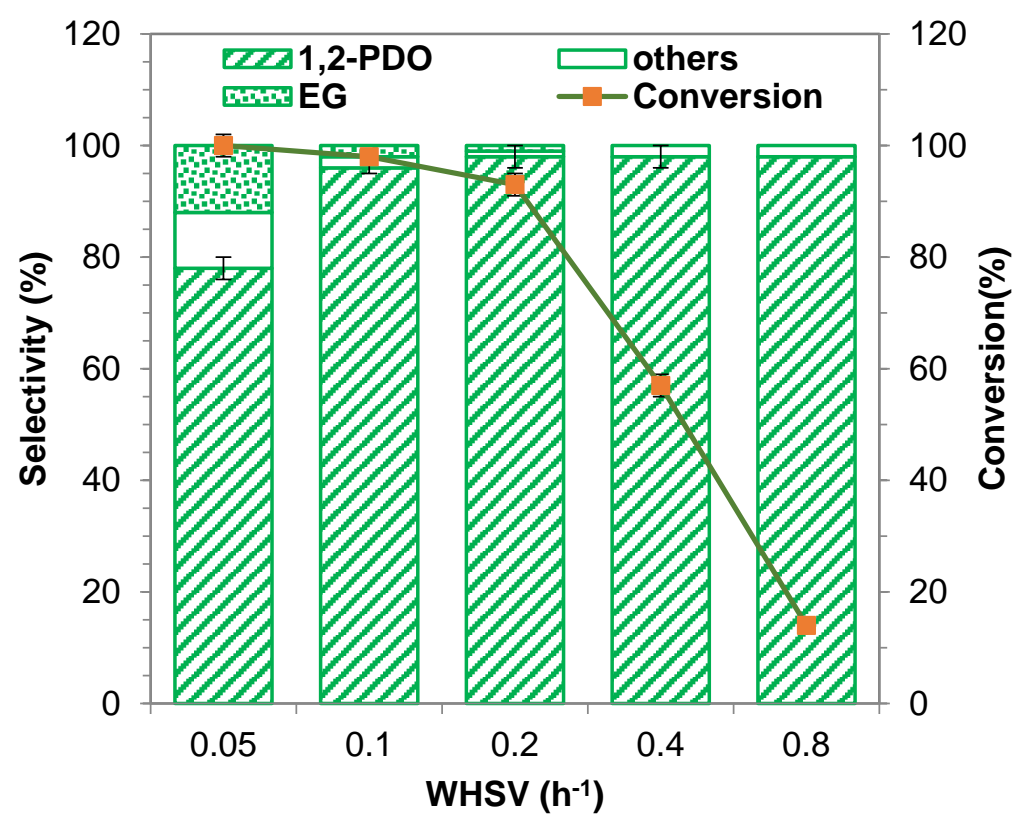

Figure 7. Influence of WHSV $\left(0.05-0.8 \mathrm{~h}^{-1}\right)$ on the performance of $5 \mathrm{Cu}-1 \mathrm{~B} / \mathrm{Al}_{2} \mathrm{O}_{3}$ catalyst for glycerol hydrogenolysis $\left(250{ }^{\circ} \mathrm{C}, 6 \mathrm{MPa} \mathrm{H}_{2}, 10 \mathrm{wt} \%\right.$ aq. glycerol).

\subsubsection{Influence of Glycerol Feedstock Purity}

One of the objectives of the present work was to evaluate the possibility of using low-grade glycerol for hydrogenolysis to 1,2-PDO. Specifically, crude glycerol (54.7\% purity) and technical grade glycerol ( $91.6 \%$ purity) were tested, in comparison to pharmaceutical grade glycerol ( $99.9 \%$ purity). The mass composition of different grades of glycerol used in this work is given in Table 3. It was assumed that the presence of impurities would adversely affect the performance of the catalyst, as discussed previously. For instance, the presence of water would impose a thermodynamic barrier, limiting the reaction. The salt impurities could deactivate the catalyst surface and other organic impurities present in crude glycerol could compete with glycerol in the adsorption process on the catalyst surface, hence, reducing the glycerol conversion and 1,2-PDO selectivity.

Table 3. Composition of different grades of glycerol.

\begin{tabular}{ccccc}
\hline Glycerol Grade & Purity (\%) & Water (\%) & Ash (\%) & MONG $^{\mathbf{1}} \mathbf{( \% )}$ \\
\hline Pharmaceutical & 99.9 & 0.1 & $<0.001$ & N.D \\
Technical & 91.6 & 4.3 & 1.4 & 2.7 \\
Crude & 54.7 & 12.8 & 7.3 & 25.2 \\
\hline
\end{tabular}

${ }^{1}$ MONG: matter organic non-glycerol; N.D: not detected. 
Figure 8 shows the glycerol conversions and selectivity of different products achieved with different grades of glycerol with $5 \mathrm{Cu}-1 \mathrm{~B} / \mathrm{Al}_{2} \mathrm{O}_{3}$ catalyst at the reaction conditions of $250{ }^{\circ} \mathrm{C}, 10 \mathrm{wt} \%$ aq. solution, $6 \mathrm{MPa}$, WHSV $0.1 \mathrm{~h}^{-1}$. As expected, reactions performed with technical grade and crude glycerol resulted in substantially reduced glycerol conversion and 1,2-PDO selectivity, which clearly indicates the negative impact of the impurities in the glycerol feedstock on the hydrogenolysis of glycerol due to the deactivation of the catalyst [11].

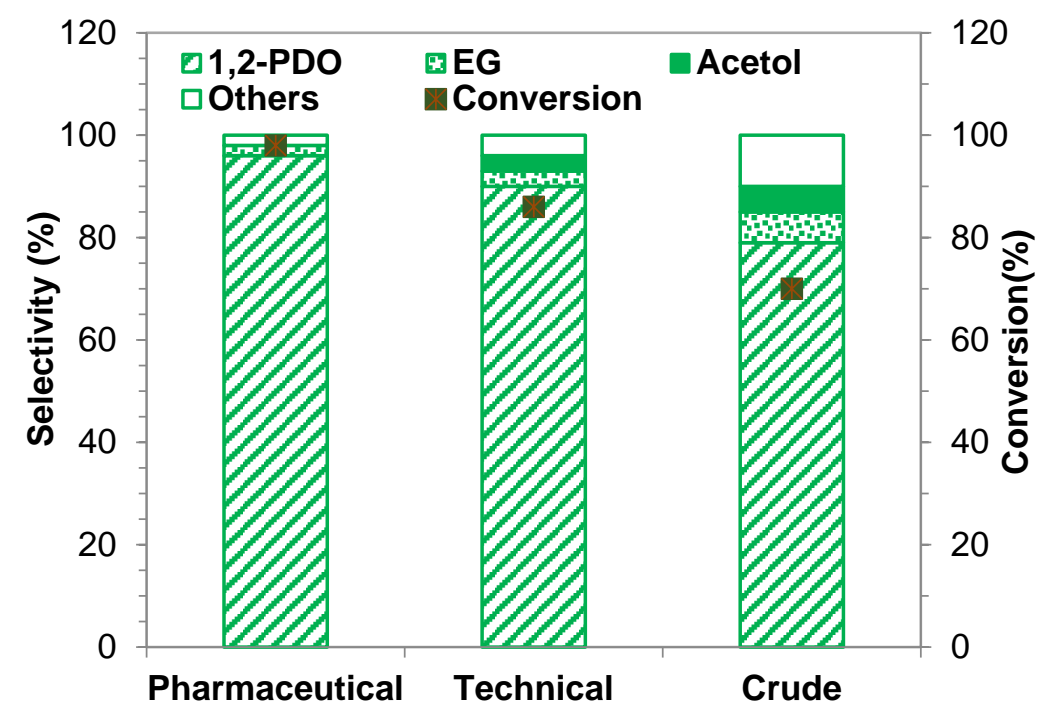

Figure 8. Influence of different grades of glycerol on glycerol conversion and product selectivities with $5 \mathrm{Cu}-1 \mathrm{~B} / \mathrm{Al}_{2} \mathrm{O}_{3}$ catalyst (reaction conditions: $250{ }^{\circ} \mathrm{C}, 10 \mathrm{wt} \%$ aq. glycerol feedstock, $6 \mathrm{MPa}$, WHSV $\left.0.1 \mathrm{~h}^{-1}\right)$.

\subsection{Long-Term Stability and Catalyst Deactivation}

The long-term performance of hydrogenolysis of pure glycerol over $5 \mathrm{Cu}-1 \mathrm{~B} / \mathrm{Al}_{2} \mathrm{O}_{3}$ catalyst was tested at $250{ }^{\circ} \mathrm{C}, 6 \mathrm{MPa} \mathrm{H}$ flow, and $0.1 \mathrm{~h}^{-1}$, and the results are given in Figure 9. No sign of any decline in the catalyst activity ( $>95 \%$ glycerol conversion and $>97 \%$ 1,2-PDO selectivity) was observed up to $60 \mathrm{~h}$, despite the harsh reaction conditions, which suggest the promise of the $5 \mathrm{Cu}-1 \mathrm{~B} / \mathrm{Al}_{2} \mathrm{O}_{3}$ catalyst for industrial applications. After this time, the glycerol conversion gradually decreased. Meanwhile, the product distribution did not show any appreciable change during this period. These results are in good-agreement with those reported in the literature [34].The list of different products with their selectivity after the first hour of reaction is given in Table 4 .

Deactivation of the catalyst was observed after $60 \mathrm{~h}$ on stream, as shown in Figure 9. Usually, in a heterogeneous system, the catalyst deactivation occurs due to destruction of the support structure, sintering, coking, fouling, or leaching of the catalyst [51]. Comparing the surface area and the pore volume of the fresh and spent catalyst (Table 1), it is revealed that both the BET surface area and total pore volume for the spent catalyst were reduced, suggesting the destruction of the support, sintering of the $\mathrm{Cu}$ metal, or deposition of fouling materials inside the pores of the $5 \mathrm{Cu}-1 \mathrm{~B} / \mathrm{Al}_{2} \mathrm{O}_{3}$ catalyst might occur during the long-term test. To prove this hypothesis, TEM, TGA, and ICP-AES analysis were performed on the fresh and spent (after $70 \mathrm{~h}$ on stream) catalysts of $5 \mathrm{Cu}-1 \mathrm{~B} / \mathrm{Al}_{2} \mathrm{O}_{3}$. TEM micrographs of fresh and spent catalyst are illustrated in Figure 10a,b, where the presence of $\mathrm{Cu}$ particles was confirmed by Energy Dispersive X-Ray Analysis (EDX). Limited by the magnification of the TEM instrument, however, only clusters of the $\mathrm{Cu}$ particles were observable in the fresh and spent catalysts.

Figure 11 shows the TG thermogram of fresh and spent catalysts of $5 \mathrm{Cu}-1 \mathrm{~B} / \mathrm{Al}_{2} \mathrm{O}_{3}$ after $70 \mathrm{~h}$ on stream. The TGA measurements were performed at $10^{\circ} \mathrm{C} /$ min over a temperature range of $50{ }^{\circ} \mathrm{C}$ to $800^{\circ} \mathrm{C}$ under a constant flow of air of $20 \mathrm{~mL} / \mathrm{min}$. From the TG thermograms of the fresh and spent catalysts, a total of $30 \mathrm{wt} \%$ weight loss was observed over the range of $50{ }^{\circ} \mathrm{C}$ to $800{ }^{\circ} \mathrm{C}$ for the spent 
catalyst, compared with only $<8 \mathrm{wt} \%$ weight loss for the fresh catalyst. This result may evidence the deposition of fouling materials due to polymerization of glycerol on the spent catalyst, which could contribute to the deactivation of the catalyst by blocking the catalyst active sites.

Moreover, the concentration of $\mathrm{Cu}, \mathrm{B}$ and $\mathrm{Al}$ in the fresh and the spent catalyst was measured by ICP-AES and given in Table 1. A negligible change in the concentration of $\mathrm{Cu}$ between the fresh and spent catalyst was observed $(4.79 \%$ to $4.46 \%)$ indicating a trivial role of leaching on the catalyst deactivation. However, a significant change in the concentration of $\mathrm{B}$ and $\mathrm{Al}$ was observed in the spent catalyst indicating the destruction of the support structure in a long run that facilitates the deactivation of the catalyst.

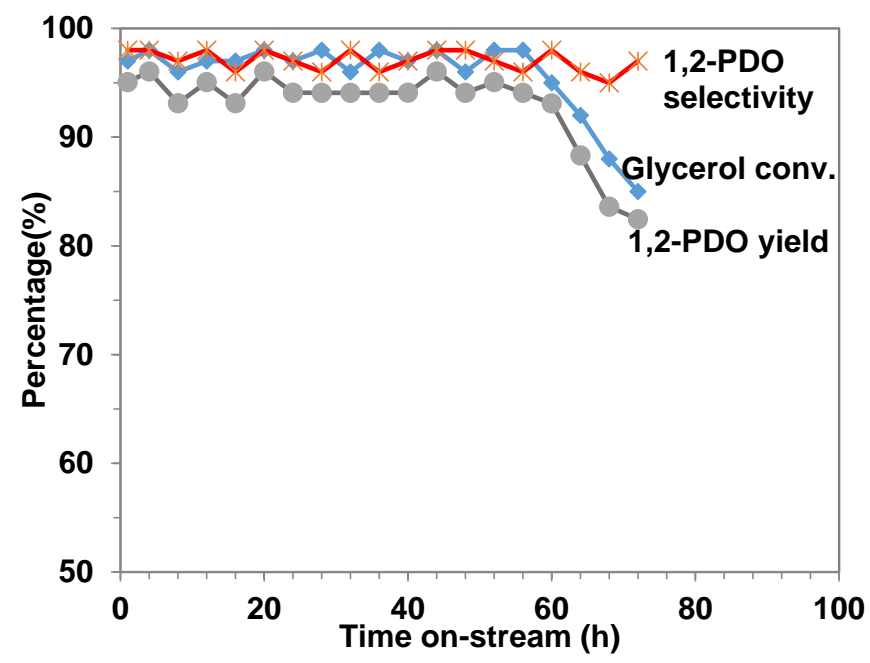

Figure 9. Long term stability of $5 \mathrm{Cu}-1 \mathrm{~B} / \mathrm{Al}_{2} \mathrm{O}_{3}$ catalyst in glycerol hydrogenolysis conducted at $250{ }^{\circ} \mathrm{C}$, $6 \mathrm{MPa} \mathrm{H}_{2}$ flow and $0.1 \mathrm{~h}^{-1}$.

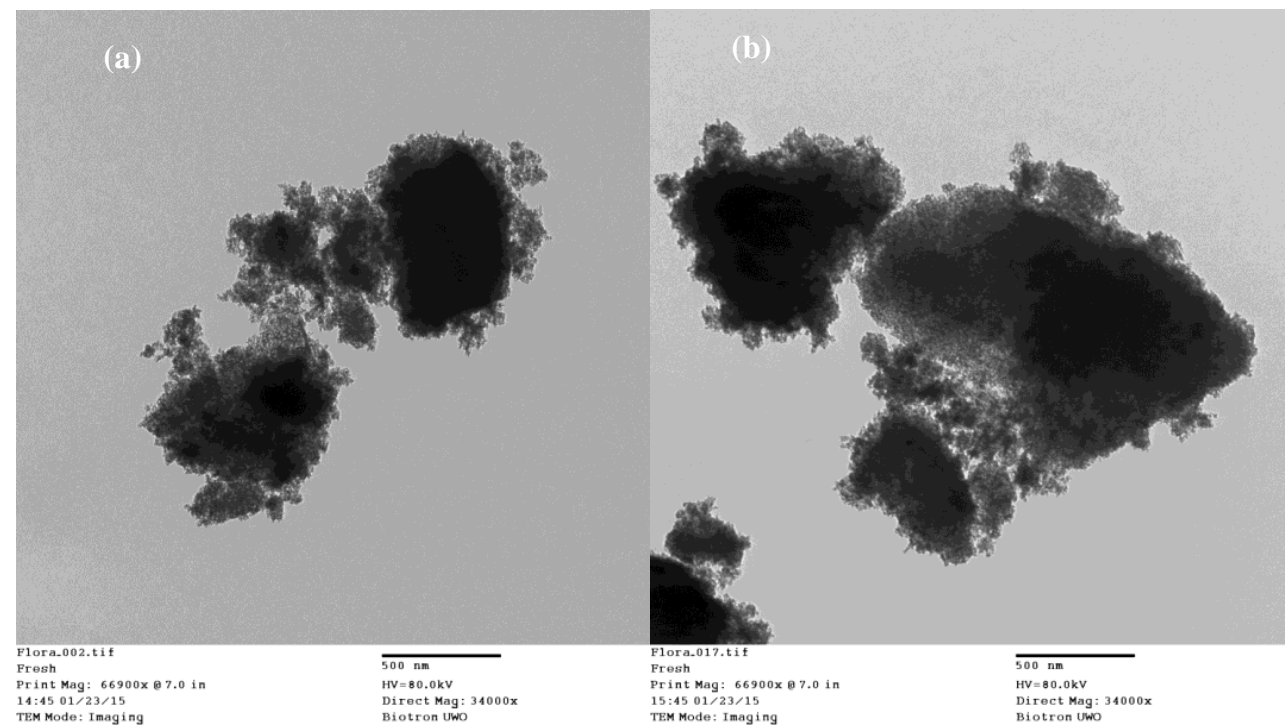

Figure 10. TEM micrographs of fresh (a) and spent catalyst $(\mathbf{b})$ of $5 \mathrm{Cu}-1 \mathrm{~B} / \mathrm{Al}_{2} \mathrm{O}_{3}$ after $70 \mathrm{~h}$ on stream.

Table 4. List of different products with their selectivity.

\begin{tabular}{lccccccc}
\hline \multirow{2}{*}{\begin{tabular}{c} 
Catalyst \\
\cline { 3 - 8 }
\end{tabular}} & \multirow{2}{*}{ Conversion (\%) } & \multicolumn{7}{c}{ Selectivity (\%) } \\
\cline { 2 - 8 } & & 1,2-PDO & EG & Acetol & 1-PrOH & 2-PrOH & EtOH \\
\hline $5 \mathrm{Cu}-1 \mathrm{~B} / \mathrm{Al}_{2} \mathrm{O}_{3}$ & $98 \pm 2$ & $98 \pm 2.0$ & $0.6 \pm 0.03$ & $0.2 \pm 0.04$ & $0.6 \pm 0.02$ & $0.4 \pm 0.04$ & $0.2 \pm 0.03$ \\
\hline
\end{tabular}




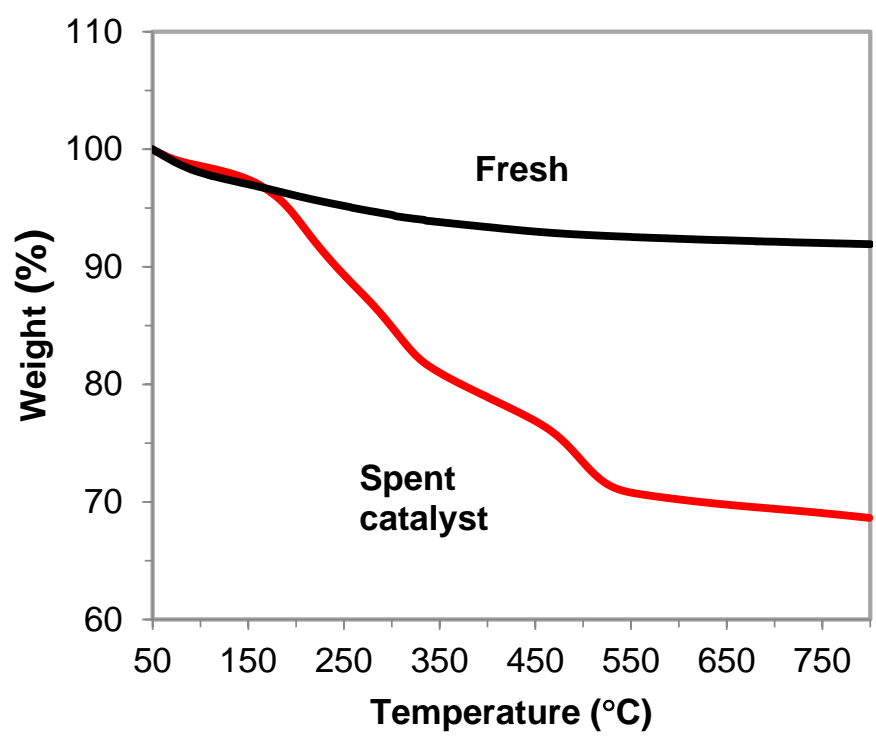

Figure 11. Thermogravimetric analysis of fresh and spent catalyst of $5 \mathrm{Cu}-1 \mathrm{~B} / \mathrm{Al}_{2} \mathrm{O}_{3}$ after $70 \mathrm{~h}$ on stream.

\section{Materials and Methods}

\subsection{Materials}

Glycerol (99.9\%), and methanol (99\%), were purchased from Sigma Aldrich Canada (Oakville, ON, Canada) and used as received. Reagent-grade anhydrous ethanol was supplied from Commercial Alcohols Inc (Toronto, ON, Canada). 1,2-propanediol (99.9\%), 1,3-propanediol (99.9\%), ethylene glycerol (99.9\%), acetol (99.8\%), n-propanol (99.99\%), and 1-butanol for GC calibration were also obtained from Sigma Aldrich Canada. Copper nitrate, $\gamma$ - alumina, and boric acid were purchased from Sigma Aldrich Canada. High purity gases, hydrogen and nitrogen ( $>99.999 \%)$, were obtained from Praxair, Canada Inc (London, ON, Canada).

\subsection{Catalyst Preparation}

Firstly, a Cu/ $\mathrm{Al}_{2} \mathrm{O}_{3}$ catalyst was prepared by wet impregnation method [34] using a calculated amount of water-soluble metal salt of copper (II) nitrate hydrate $\left[\mathrm{Cu}\left(\mathrm{NO}_{3}\right)_{2} \cdot 3 \mathrm{H}_{2} \mathrm{O}\right]$ and $\gamma-\mathrm{Al}_{2} \mathrm{O}_{3}$ as the support material. The catalyst was then dried at $90{ }^{\circ} \mathrm{C}$ for $12 \mathrm{~h}$ to form the $\mathrm{Cu} / \mathrm{Al}_{2} \mathrm{O}_{3}$ precursor. The $\mathrm{B}_{2} \mathrm{O}_{3}$-modified $\mathrm{Cu} / \mathrm{Al}_{2} \mathrm{O}_{3}$ catalysts were prepared by incipient wetness impregnation of the $\mathrm{Cu} / \mathrm{Al}_{2} \mathrm{O}_{3}$ precursor with aqueous solutions containing the desired amount of $\mathrm{H}_{3} \mathrm{BO}_{3}$. After impregnation, these samples were dried overnight at $90{ }^{\circ} \mathrm{C}$ and then calcined at $400{ }^{\circ} \mathrm{C}$ for $5 \mathrm{~h}$ under a $\mathrm{N}_{2}$ flow of $20 \mathrm{~mL} / \mathrm{min}$ at a heating rate of $2{ }^{\circ} \mathrm{C} / \mathrm{min}$. The obtained catalysts are designated as $\mathrm{xCu}-\mathrm{yB} / \mathrm{Al}_{2} \mathrm{O}_{3}$, where $\mathrm{x}$ and $\mathrm{y}$ represent the mass loading of copper and boron, respectively.

\subsection{Catalyst Characterization}

The surface area, total pore volume, and average pore diameter of the selected catalysts were determined by nitrogen isothermal (at $-196{ }^{\circ} \mathrm{C}$ ) adsorption with a Micromeritics ASAP 2010 BET apparatus after degassing the samples at $300{ }^{\circ} \mathrm{C}$ for $8 \mathrm{~h}$ in vacuum.

The acidity of the catalysts were measured by an ammonia temperature programmed desorption $\left(\mathrm{NH}_{3}\right.$-TPD) test using Micromeritics AutoChem II analyzer. Around $0.35 \mathrm{~g}$ of the non-reduced calcined catalyst was pretreated in $\mathrm{He}$ at $400{ }^{\circ} \mathrm{C}$ to remove moisture and other adsorbed gases on the surface for $1 \mathrm{~h}$. After cooling to $100{ }^{\circ} \mathrm{C}$, the catalyst was saturated with pure $\mathrm{NH}_{3}$ for $30 \mathrm{~min}$, and then purged with $\mathrm{He}$ to remove the physiosorbed $\mathrm{NH}_{3}$ for $30 \mathrm{~min}$. The sample was heated to $700{ }^{\circ} \mathrm{C}$ at a ramp rate of $5{ }^{\circ} \mathrm{C} / \mathrm{min}$ and the $\mathrm{NH}_{3}$ desorbed was detected by a mass spectrometer. 
The crystal structures of selected catalysts were examined by powder X-ray diffraction (XRD) with a PANalytical X'Pert Pro diffractometer with $\mathrm{Cu} \mathrm{K} \alpha$ as the radiation source. Step-scans were taken over the range of $2 \theta$ from 6 to $95^{\circ}$.

Temperature-programmed reduction (TPR) profiles of the catalysts were determined using a Micromeritics Autochem 2920 equipped with a thermal conductivity detector (TCD). These catalysts were first heated from ambient temperature to $550{ }^{\circ} \mathrm{C}$ at $10{ }^{\circ} \mathrm{C} /$ min under a $5 \% \mathrm{O}_{2} /$ He mixture flow at $50 \mathrm{~mL} / \mathrm{min}$ for pre-treatment and then exposed to a flowing gas composed of $\mathrm{H}_{2}$ and $\mathrm{Ar}(v / v=1: 9)$ at $50 \mathrm{~mL} / \mathrm{min}$ and were heated from room temperature to $700^{\circ} \mathrm{C}$ at a heating rate of $10^{\circ} \mathrm{C} / \mathrm{min}$.

The morphologies of the spent catalyst were analyzed using a JEOL $2100 \mathrm{~F}$ transmission electron microscope equipped with an energy-dispersive X-ray spectroscopy (EDS-INCA system from Oxford Instrument).

The thermogravimetric analysis (TGA) of the fresh/spent catalysts was conducted on a thermogravimetric analysis unit (Perkin Elmer Pyris 1 TGA unit). The TGA measurements were performed at $10{ }^{\circ} \mathrm{C} / \mathrm{min}$ over a temperature range of $50{ }^{\circ} \mathrm{C}$ to $800{ }^{\circ} \mathrm{C}$ under a constant flow of air of $20 \mathrm{~mL} / \mathrm{min}$.

The ICP-AES analysis of the selective fresh and spent catalysts was performed by a certified analytical lab—Lakehead University Instrumentation Lab—following its well-established protocol.

\subsection{Catalytic Tests}

The hydrogenolysis of glycerol was carried out in a bench scale continuous down-flow tubular reactor (Inconel 316 tubing, $9.55 \mathrm{~mm}$ OD, $6.34 \mathrm{~mm}$ ID and $600 \mathrm{~mm}$ length) heated with an electric furnace. Typically, around $2.0 \mathrm{~g}$ of the catalyst was loaded in the constant temperature section of the reactor and supported on a porous Inconel metal disc (pore size: $100 \mu \mathrm{m}$ ) and some quartz wool. Prior to each run, the catalyst was reduced in situ in flowing $\mathrm{H}_{2}\left(100 \mathrm{~cm}^{3} / \mathrm{min}\right)$ at $300{ }^{\circ} \mathrm{C}$ for $3 \mathrm{~h}$ at atmospheric pressure. The feed-a $10 \mathrm{wt} \%$ aqueous solution of glycerol (unless otherwise mentioned) - was pumped using a HPLC pump (Eldex) at a predetermined flow rate into the reactor. This translates to a corresponding WHSV, which is the mass of the glycerol per mass of catalyst per hour. All of the experiments are performed at a desired temperature and pressure (controlled by a temperature controller and a back-pressure controller, respectively) along with co-feeding of $\mathrm{H}_{2}$ gas. The liquid and gas products were cooled and collected in a gas-liquid separator immersed in an ice-water trap.

\subsection{Product Analysis}

All the liquid components in the reaction mixture were analyzed by GC-MS on a Varian 1200 Quadrupole MS (EI) and Varian CP-3800 GC with VF-5 MS column (5\% phenyl/95\% dimethyl-polysiloxane, $30 \mathrm{~m} \times 0.25 \mathrm{~mm} \times 0.25 \mu \mathrm{m}$ ) using helium as the carrier gas at a flow rate of $0.5 \mathrm{~mL} / \mathrm{s}$. The oven temperature was maintained at $70{ }^{\circ} \mathrm{C}$ for $1 \mathrm{~min}$ and then increased to $290{ }^{\circ} \mathrm{C}$ at $40{ }^{\circ} \mathrm{C} / \mathrm{min}$. Injector and detector temperature were $300{ }^{\circ} \mathrm{C}$. The components were identified by the NIST 98 MS library. Quantification of the chemical composition was performed on a GC-FID (Shimadzu-2010), from Shimadzu Scientific Instruments (Guelph, ON, Canada), calibrated with 1,2-PDO (99.9\%), ethylene glycol (99.9\%), and acetol (99.8\%). Dimethyl sulfoxide (DMSO) was used as the internal standard. The GC-FID analysis was carried out using the similar separation conditions as mentioned above for the GC-MS analysis. The gas samples were analyzed by a GC-TCD (Agilent 3000 Micro-GC).

The reported yield and conversion are values after $4 \mathrm{~h}$ on-stream unless otherwise specified. Herewith, the product yield, glycerol conversion, and product selectivity are defined as follows:

$$
\text { Yield }(\%)=\frac{\text { Moles of the product formed }}{\text { Initial mole of glycerol }} \times 100
$$




$$
\begin{aligned}
& \text { Conversion }(\%)=\frac{\text { Initial mole of glycerol }- \text { Final mole of glycerol }}{\text { Initial mole of glycerol }} \times 100 \\
& \text { Selectivity }(\%)=\frac{\text { Moles of the product formed }}{\text { Initial mole of glycerol }- \text { Final mole of glycerol }} \times 100=\text { Yield/Conversion }
\end{aligned}
$$

\section{Conclusions}

The addition of $\mathrm{B}_{2} \mathrm{O}_{3}$ to $\mathrm{Cu} / \mathrm{Al}_{2} \mathrm{O}_{3}$ catalysts enhanced the catalytic activity for the hydrogenolysis of glycerol to 1,2-PDO. Among all catalysts prepared and tested, $5 \mathrm{Cu}-1 \mathrm{~B} / \mathrm{Al}_{2} \mathrm{O}_{3}$ demonstrated the best catalytic performance with $98 \pm 2 \%$ glycerol conversion and $98 \pm 2 \% 1$,2-PDO selectivity in hydrogenolysis of $10 \mathrm{wt} \%$ aqueous solution of glycerol at the optimum conditions $\left(250{ }^{\circ} \mathrm{C}, 6 \mathrm{MPa}\right.$ $\mathrm{H}_{2}$ pressure, and $0.1 \mathrm{~h}^{-1}$ WHSV). Process parameters, such as temperature, hydrogen pressure, and liquid hourly space velocity, significantly influenced the catalytic activity for the glycerol hydrogenolysis reaction. The use of different grades of glycerol, including pharmaceutical-grade glycerol, technical-grade glycerol, and crude glycerol (glycerol purity varying from 54.7 to $99.9 \%$ ) showed that the presence of impurities could reduce the glycerol conversion and 1,2-PDO selectivity. The long-term stability test demonstrated that the $5 \mathrm{Cu}-1 \mathrm{~B} / \mathrm{Al}_{2} \mathrm{O}_{3}$ catalyst could be used up to $60 \mathrm{~h}$ without any appreciable change in activity. Destruction of the support structure, sintering of $\mathrm{Cu}$ metal, and coke deposition on the catalyst might be the main factors that deactivated the catalyst after $60 \mathrm{~h}$ on stream. The promoting effects of boron for the activities of $\mathrm{Cu} / \mathrm{Al}_{2} \mathrm{O}_{3}$ catalysts might be attributed to the strong interaction between $\mathrm{Cu}$ and $\mathrm{B}$ species that helped retard the aggregation of $\mathrm{Cu}$ particles during calcination, reduction, and reaction, as evidenced by $\mathrm{H}_{2}$-TPR profiles. In addition, as evidenced by the $\mathrm{NH}_{3}$-TPD profiles of the catalysts, the addition of $\mathrm{B}_{2} \mathrm{O}_{3}$ enhanced the acidity of the $\mathrm{Cu} / \mathrm{Al}_{2} \mathrm{O}_{3}$ catalysts, which would also play a role in the enhancement of catalytic activities of the catalysts.

Acknowledgments: The authors wish to acknowledge the financial support provided by Natural Science and Engineering Research Council of Canada (NSERC) through the Discovery Grant and Industrial Research Chair for $\mathrm{Xu}$, as well as from Mitacs through the Accelerate program. We are also grateful to Yasuo Ohtsuka for his invaluable suggestions on some aspects of this research.

Author Contributions: Hengfu Shui and Chunbao (Charles) Xu conceived and designed the experiments; Malaya R. Nanda and Zhongshun Yuan performed the experiments and analyzed the data; and Malaya R. Nanda wrote the paper.

Conflicts of Interest: The authors declare no conflict of interest.

\section{References}

1. Maris, E.; Ketchie, W.; Murayama, M.; Davis, R. Glycerol hydrogenolysis on carbon-supported PtRu and AuRu bimetallic catalysts. J. Catal. 2007, 251, 281-294. [CrossRef]

2. Yuan, Z.; Wang, J.; Wang, L.; Xie, W.; Chen, P.; Hou, Z.; Zheng, X. Biodiesel derived glycerol hydrogenolysis to 1,2-propanediol on $\mathrm{Cu} / \mathrm{MgO}$ catalysts. Bioresour. Technol. 2010, 101, 7099-7103. [CrossRef] [PubMed]

3. Nanda, M.R.; Yuan, Z.; Qin, W.; Ghaziaskar, H.S.; Poirier, M.-A.; Xu, C. A new continuous-flow process for catalytic conversion of glycerol to oxygenated fuel additive: Catalyst screening. Appl. Energy 2014, 123, 75-81. [CrossRef]

4. Nanda, M.R.; Yuan, Z.; Qin, W.; Ghaziaskar, H.S.; Poirier, M.-A.; Xu, C. Thermodynamic and kinetic studies of a catalytic process to convert glycerol into solketal as an oxygenated fuel additive. Fuel 2014, 117, 470-477. [CrossRef]

5. Behr, A.; Eilting, J.; Irawadi, K.; Leschinski, J.; Lindner, F. Improved utilisation of renewable resources: New important derivatives of glycerol. Green Chem. 2008, 10, 13-30. [CrossRef]

6. Ma, L.; He, D.; Li, Z. Promoting effect of rhenium on catalytic performance of Ru catalysts in hydrogenolysis of glycerol to propanediol. Catal. Commun. 2008, 9, 2489-2495. [CrossRef]

7. Feng, J.; Fu, H.; Wang, J.; Li, R.; Chen, H.; Li, X. Hydrogenolysis of glycerol to glycols over ruthenium catalysts: Effect of support and catalyst reduction temperature. Catal. Commun. 2008, 9, 1458-1464. [CrossRef]

8. Sharma, R.V.; Kumar, P.; Dalai, A.K. Selective hydrogenolysis of glycerol to propylene glycol by using Cu:Zn:Cr:Zr mixed metal oxides catalyst. Appl. Catal. A Gen. 2014, 477, 147-156. [CrossRef] 
9. Yuan, Z.; Wang, L.; Wang, J.; Xia, S.; Chen, P.; Hou, Z.; Zheng, X. Hydrogenolysis of glycerol over homogenously dispersed copper on solid base catalysts. Appl. Catal. B Environ. 2011, 101, 431-440. [CrossRef]

10. Xia, S.; Yuan, Z.; Wang, L.; Chen, P.; Hou, Z. Hydrogenolysis of glycerol on bimetallic Pd-Cu/solid-base catalysts prepared via layered double hydroxides precursors. Appl. Catal. A Gen. 2011, 403, 173-182. [CrossRef]

11. Atia, H.; Armbruster, U.; Martin, A. Dehydration of glycerol in gas phase using heteropolyacid catalysts as active compounds. J. Catal. 2008, 258, 71-82. [CrossRef]

12. Auttanat, T.; Jongpatiwut, S.; Rirksomboon, T. Dehydroxylation of glycerol to propylene glycol over $\mathrm{Cu}-\mathrm{ZnO} / \mathrm{Al}_{2} \mathrm{O}_{3}$ Catalyst: Effect of feed purity. World Acad. Sci. Technol. 2012, 6, 400-403.

13. Barbelli, M.L.; Santori, G.F.; Nichio, N.N. Aqueous phase hydrogenolysis of glycerol to bio-propylene glycol over Pt-Sn catalysts. Bioresour. Technol. 2012, 111, 500-503. [CrossRef] [PubMed]

14. Dasari, M.; Kiatsimkul, P.-P.; Sutterlin, W.R.; Suppes, G.J. Low-pressure hydrogenolysis of glycerol to propylene glycol. Appl. Catal. A Gen. 2005, 281, 225-231. [CrossRef]

15. Deng, C.; Duan, X.; Zhou, J.; Chen, D.; Zhou, X.; Yuan, W. Size effects of Pt-Re bimetallic catalysts for glycerol hydrogenolysis. Catal. Today 2014, 234, 208-214. [CrossRef]

16. D'Hondt, E.; Van de Vyver, S.; Sels, B.F.; Jacobs, P. Catalytic glycerol conversion into 1,2-propanediol in absence of added hydrogen. Chem. Commun. 2008, 6011-6012. [CrossRef] [PubMed]

17. Kim, N.D.; Park, J.R.; Park, D.S.; Kwak, B.K.; Yi, J. Promoter effect of Pd in $\mathrm{CuCr}_{2} \mathrm{O}_{4}$ catalysts on the hydrogenolysis of glycerol to 1,2-propanediol. Green Chem. 2012, 14, 2638-2646. [CrossRef]

18. Balaraju, M.; Rekha, V.; Prasad, P.S.S.; Devi, B.L.A.P.; Prasad, R.B.N.; Lingaiah, N. Influence of solid acids as co-catalysts on glycerol hydrogenolysis to propylene glycol over Ru/C catalysts. Appl. Catal. A Gen. 2009, 354, 82-87. [CrossRef]

19. Zhou, C.-H.C.; Beltramini, J.N.; Fan, Y.-X.; Lu, G.Q.M. Chemoselective catalytic conversion of glycerol as a biorenewable source to valuable commodity chemicals. Chem. Soc. Rev. 2008, 37, 527-549. [CrossRef] [PubMed]

20. Vasiliadou, E.S.; Eggenhuisen, T.M.; Munnik, P.; de Jongh, P.E.; de Jong, K.P.; Lemonidou, A.A. Synthesis and performance of highly dispersed $\mathrm{Cu} / \mathrm{SiO}_{2}$ catalysts for the hydrogenolysis of glycerol. Appl. Catal. B Environ. 2014, 145, 108-119. [CrossRef]

21. Gandarias, I.; Arias, P.L.; Requies, J.; El Doukkali, M.; Güemez, M.B. Liquid-phase glycerol hydrogenolysis to 1,2-propanediol under nitrogen pressure using 2-propanol as hydrogen source. J. Catal. 2011, 282, $237-247$. [CrossRef]

22. Xiao, Z.; Wang, X.; Xiu, J.; Wang, Y.; Williams, C.T.; Liang, C. Synergetic effect between $\mathrm{Cu}^{0}$ and $\mathrm{Cu}^{+}$in the $\mathrm{Cu}-\mathrm{Cr}$ catalysts for hydrogenolysis of glycerol. Catal. Today 2014, 234, 200-207. [CrossRef]

23. Panyad, S.; Jongpatiwut, S.; Sreethawong, T.; Rirksomboon, T.; Osuwan, S. Catalytic dehydroxylation of glycerol to propylene glycol over $\mathrm{Cu}-\mathrm{ZnO} / \mathrm{Al}_{2} \mathrm{O}_{3}$ catalysts: Effects of catalyst preparation and deactivation. Catal. Today 2011, 174, 59-64. [CrossRef]

24. Chaminand, J.; Djakovitch, L.; Gallezot, P.; Marion, P.; Pinel, C.; Rosier, C. Glycerol hydrogenolysis on heterogeneous catalysts. Green Chem. 2004, 6, 359-361. [CrossRef]

25. Miyazawa, T.; Kusunoki, Y.; Kunimori, K.; Tomishige, K. Glycerol conversion in the aqueous solution under hydrogen over $\mathrm{Ru} / \mathrm{C}+$ an ion-exchange resin and its reaction mechanism. J. Catal. 2006, 240, $213-221$. [CrossRef]

26. Schmidt, S.R.; Tanielyan, S.K.; Marin, N.; Alvez, G.; Augustine, R.L. Selective conversion of glycerol to propylene glycol over fixed bed Raney ${ }^{\circledR} \mathrm{Cu}$ catalysts. Top. Catal. 2010, 53, 1214-1216. [CrossRef]

27. Zhu, S.; Gao, X.; Zhu, Y.; Zhu, Y.; Zheng, H.; Li, Y. Promoting effect of boron oxide on $\mathrm{Cu} / \mathrm{SiO}_{2}$ catalyst for glycerol hydrogenolysis to 1,2-propanediol. J. Catal. 2013, 303, 70-79. [CrossRef]

28. Mizugaki, T.; Arundhathi, R.; Mitsudome, T.; Jitsukawa, K.; Kaneda, K. Selective hydrogenolysis of glycerol to 1,3-propanediol catalyzed by Pt nanoparticles- $\mathrm{AlO}_{x} / \mathrm{WO}_{3}$. Chem. Lett. 2013, 42, 729-731. [CrossRef]

29. Furikado, I.; Miyazawa, T.; Koso, S.; Shimao, A.; Kunimori, K.; Tomishige, K. Catalytic performance of $\mathrm{Rh} / \mathrm{SiO} 2$ in glycerol reaction under hydrogen. Green Chem. 2007, 9, 582-588. [CrossRef]

30. Huang, Z.; Liu, H.; Cui, F.; Zuo, J.; Chen, J.; Xia, C. Effects of the precipitation agents and rare earth additives on the structure and catalytic performance in glycerol hydrogenolysis of $\mathrm{Cu} / \mathrm{SiO}_{2}$ catalysts prepared by precipitation-gel method. Catal. Today 2014, 234, 223-232. [CrossRef] 
31. Huang, Z.; Cui, F.; Xue, J.; Zuo, J.; Chen, J.; Xia, C. Cu/SiO 2 catalysts prepared by hom- and heterogeneous deposition-precipitation methods: Texture, structure, and catalytic performance in the hydrogenolysis of glycerol to 1,2-propanediol. Catal. Today 2012, 183, 42-51. [CrossRef]

32. Wang, S.; Liu, H. Selective hydrogenolysis of glycerol to propylene glycol on Cu-ZnO catalysts. Catal. Lett. 2007, 117, 62-67. [CrossRef]

33. Bienholz, A.; Schwab, F.; Claus, P. Hydrogenolysis of glycerol over a highly active CuO/ZnO catalyst prepared by an oxalate gel method: Influence of solvent and reaction temperature on catalyst deactivation. Green Chem. 2010, 12, 290-295. [CrossRef]

34. Hao, S.-L.; Peng, W.-C.; Zhao, N.; Xiao, F.-K.; Wei, W.; Sun, Y.-H. Hydrogenolysis of glycerol to 1,2-propanediol catalyzed by $\mathrm{Cu}-\mathrm{H} 4 \mathrm{SiW} 12 \mathrm{O} 40 / \mathrm{Al}_{2} \mathrm{O}_{3}$ in liquid phase. J. Chem. Technol. Biotechnol. 2010, 85, 1499-1503. [CrossRef]

35. Vila, F.; López Granados, M.; Ojeda, M.; Fierro, J.L.G.; Mariscal, R. Glycerol hydrogenolysis to 1,2-propanediol with $\mathrm{Cu} / \gamma-\mathrm{Al}_{2} \mathrm{O}_{3}$ : Effect of the activation process. Catal. Today 2012, 187, 122-128. [CrossRef]

36. Niu, L.; Wei, R.; Yang, H.; Li, X.; Jiang, F.; Xiao, G. Hydrogenolysis of glycerol to propanediols over $\mathrm{Cu}-\mathrm{MgO} / \mathrm{USY}$ catalyst. Chin. J. Catal. 2013, 34, 2230-2235. [CrossRef]

37. Xia, S.; Yuan, Z.; Wang, L.; Chen, P.; Hou, Z. Catalytic production of 1,2-propanediol from glycerol in bio-ethanol solvent. Bioresour. Technol. 2012, 104, 814-817. [CrossRef] [PubMed]

38. Zheng, J.; Xia, Z.; Li, J.; Lai, W.; Yi, X.; Chen, B.; Fang, W.; Wan, H. Promoting effect of boron with high loading on Ni-based catalyst for hydrogenation of thiophene-containing ethylbenzene. Catal. Commun. 2012, 21, 18-21. [CrossRef]

39. Ma, L.; He, D. Influence of catalyst pretreatment on catalytic properties and performances of $\mathrm{Ru}-\mathrm{Re} / \mathrm{SiO} \mathrm{O}_{2}$ in glycerol hydrogenolysis to propanediols. Catal. Today 2010, 149, 148-156. [CrossRef]

40. Perosa, A.; Tundo, P. Selective Hydrogenolysis of Glycerol with Raney Nickel. Ind. Eng. Chem. Res. 2005, 44, 8535-8537. [CrossRef]

41. Gandarias, I.; Fernández, S.G.; El Doukkali, M.; Requies, J.; Arias, P.L. Physicochemical Study of Glycerol Hydrogenolysis Over a Ni-Cu/ $\mathrm{Al}_{2} \mathrm{O}_{3}$ Catalyst Using Formic Acid as the Hydrogen Source. Top. Catal. 2013, 56, 995-1007. [CrossRef]

42. Lewandowski, M.; Sarbak, Z. The effect of boron addition on hydrodesulfurization and hydrodenitrogenation activity of $\mathrm{NiMo} / \mathrm{Al}_{2} \mathrm{O}_{3}$ catalysts. Fuel 2000, 79, 487-495. [CrossRef]

43. Zhou, J.; Guo, L.; Guo, X.; Mao, J.; Zhang, S. Selective hydrogenolysis of glycerol to propanediols on supported Cu-containing bimetallic catalysts. Green Chem. 2010, 12, 1835-1843. [CrossRef]

44. Guerreiro, E.D.; Gorriz, O.F.; Rivarola, J.B.; Arrúa, L.A. Characterization of $\mathrm{Cu} / \mathrm{SiO}_{2}$ catalysts prepared by ion exchange for methanol dehydrogenation. Appl. Catal. A Gen. 1997, 165, 259-271. [CrossRef]

45. Tan, K.F.; Chang, J.; Borgna, A.; Saeys, M. Effect of boron promotion on the stability of cobalt Fischer-Tropsch catalysts. J. Catal. 2011, 280, 50-59.

46. Yin, A.; Qu, J.; Guo, X.; Dai, W.-L.; Fan, K. The influence of B-doping on the catalytic performance of Cu/HMS catalyst for the hydrogenation of dimethyloxalate. Appl. Catal. A Gen. 2011, 400, 39-47. [CrossRef]

47. He, Z.; Lin, H.; He, P.; Yuan, Y. Effect of boric oxide doping on the stability and activity of a Cu-SiO ${ }_{2}$ catalyst for vapor-phase hydrogenation of dimethyl oxalate to ethylene glycol. J. Catal. 2011, 277, 54-63. [CrossRef]

48. Zhao, S.; Yue, H.; Zhao, Y.; Wang, B.; Geng, Y.; Lv, J.; Wang, S.; Gong, J.; Ma, X. Chemoselective synthesis of ethanol via hydrogenation of dimethyl oxalate on $\mathrm{Cu} / \mathrm{SiO}_{2}$ : Enhanced stability with boron dopant. J. Catal. 2013, 297, 142-150. [CrossRef]

49. Martin, A.; Armbruster, U.; Gandarias, I.; Arias, P.L. Glycerol hydrogenolysis into propanediols using in situ generated hydrogen-A critical review. Eur. J. Lipid Sci. Technol. 2013, 115, 9-27. [CrossRef]

50. Vasiliadou, E.S.; Lemonidou, A. Glycerol transformation to value added C3 diols: Reaction mechanism, kinetic, and engineering aspects. Wiley Interdiscip. Rev. Energy Environ. 2014, 4, 486-520. [CrossRef]

51. Zhou, J.; Zhang, J.; Guo, X.; Mao, J.; Zhang, S. Ag/ $\mathrm{Al}_{2} \mathrm{O}_{3}$ for glycerol hydrogenolysis to 1,2-propanediol: Activity, selectivity and deactivation. Green Chem. 2012, 14, 156-163. [CrossRef]

(C) 2017 by the authors. Licensee MDPI, Basel, Switzerland. This article is an open access article distributed under the terms and conditions of the Creative Commons Attribution (CC BY) license (http:/ / creativecommons.org/licenses/by/4.0/). 